\section{İzmir İktisat Dergisi \\ İzmir Journal of Economics}

ISSN:1308-8173

$\begin{array}{ll}\text { E-ISSN: } 1308-8505 & \text { YIL: } 2021 \\ \text { Kabul Tarihi: } 12.07 .2021 & \text { Online Yayın: 05.08.2021 }\end{array}$

Geliş Tarihi: 27.06 .2020
ÖZGÜN ARAŞTIRMA
Cilt: 36 Sayı: 2 Sayfa: $365-378$

Doi: 10.24988 /ije.202136208

\title{
Döviz Kuru ve Üretici Fiyat Endeksi Arasındaki İlişkinin Sürekli Dalgacık Uyumu Modeli ile Analizi: Türkiye Üzerine Ampirik Bulgular Sevda KUŞKAYA ${ }^{1}$, Fatma ÜNLÜ ${ }^{2}$, Pelin GENÇOĞLU ${ }^{3}$ Özet
}

Bu çalışmanın amacl; Türkiye'de döviz kurlarında meydana gelen değişimlerin yurtiçi fiyatlar üzerindeki geçiş etkisini araştırmaktır. Bu amaç doğrultusunda, 2010:01-2020:04 dönemine ait döviz kuru, üretici fiyat endeksi, sanayi üretim endeksi, ihracat birim değer endeksi ve ithalat birim değer endeksi kullanılmıştır. Çalışmada yöntem olarak, değişkenler arası dalgalanmaların frekans değerlerini dikkate alan sürekli dalgacık uyumu modeli uygulanmıştır. Analiz sonuçlarından elde edilen bulgular, kısa dönemde (i) 2010:01-2013:12 periyodunda üretici fiyat endeksindeki artışların döviz kurunu artırdığını; (ii) 2014:01-2019:03 döneminde ise kurdaki artışların üretici fiyat endeksini artırdı̆̆ını göstermektedir. Uzun dönem dikkate alındığında ise, 2011:01-2013:12 ve 2016:01-2018:12 periyotlarında üretici fiyat endeksindeki artışların döviz kurunda artışlara yol açtığı tespit edilmiştir.

Anahtar kelimeler: Üretici Fiyat Endeksi, Döviz Kuru, Sürekli Dalgacık Uyumu Analizi, Türkiye Jel Kodu: F31, F39, C30

\section{The Analysis of the Relationship between Exchange Rate and Producer Price Index with Continuous Wavelet Coherence Model: Empirical Findings on Turkey}

\begin{abstract}
The purpose of this paper is to investigate the pass-through of exchange rates to domestic prices in Turkey. For this purpose, the exchange rate, producer price index, industrial production index, export unit value index, and import unit value index were used from 2010: 01 to 2020: 04. As a method, it was applied continuous wavelet coherence model which takes into consideration the frequency values of the fluctuations between variables. The results obtained from the analysis results indicate in the short term that (i) the increases in the producer price index increased the exchange rate in the period of 2010: 01-2013: 12 and (ii) the increases in the exchange rate increase the producer price index in the period of 2014: 012019: 03. In the long-term, the increase in the producer price index led to increases in the exchange rate in the periods 2011: 01-2013: 12 and 2016:01-2018:12.
\end{abstract}

Keywords: Producer Price Index, Exchange Rate, Continuous Wavelet Coherence Analysis, Turkey Jel Codes: F31, F39, C30

\section{GİRIS}

Küreselleşme olgusunun beraberinde getirdiği mal, hizmet ve finansal sermaye akımlarındaki serbestleşme hareketleri özellikle kırılgan ekonomiye sahip gelişmekte olan ülkelerdeki ekonomik sorunların daha da belirginleşmesine yol açmıştır. Nitekim bu sorunlar, Türkiye'de de 1980'li yıllardan itibaren kendisini göstermeye başlamıştır. Zira, Türkiye 24 Ocak 1980 Kararları ile birlikte dışa açık ekonomi modeline geçiş yapmış, ardından 1990'lı yıllardan itibaren de finansal serbestleşme hareketlerini gerçekleștirmiştir. Söz konusu serbestleşme hareketleri, döviz kurlarının aşırı dalgalanmasına sebep olmuştur. Çünkü ara ve yatırım malları açısından dışa bağımlılık derecesi yüksek olan

ATIF ÖNERİsí (APA): Kuşkaya, S., Ünlü, F., Gençoğlu, P. (2021). Döviz Kuru ve Üretici Fiyat Endeksi Arasındaki İlişkinin Sürekli Dalgacık Uyumu Modeli ile Analizi: Türkiye Üzerine Ampirik Bulgular. İzmir İktisat Dergisi. 36(2). 365-378.

Doi: 10.24988/ije.202136208

1 Öğr. Gör. Dr., Erciyes Üniversitesi, Adalet Meslek Yüksekokulu, Talas/KAYSERİ,

EMAIL: skuskaya@erciyes.edu.tr ORCID: 0000-0003-4527-5713

2 Doç. Dr., Erciyes Üniversitesi, İktisadi ve İdari Bilimler Fakültesi, Talas/KAYSERİ,

EMAIL: funlu@erciyes.edu.tr ORCID: 0000-0003-1822-9965

${ }^{3}$ Dr., Erciyes Üniversitesi, Kayseri Uygulama ve Araştırma Merkezi, Talas/KAYSERİ,

EMAIL: pgencoglu@erciyes.edu.tr ORCID: 0000-0003-2985-2875 
ülkelerde olduğu gibi, Türkiye'de de kurlardaki bu dalgalanmalar etkilerini genellikle fiyatlar üzerinde göstermektedir. Bu etkiler iki şekilde ortaya çıkmaktadır. Birincisi; kurlarda meydana gelen değişimlerin ithal mallarının fiyatları üzerindeki etkisi ile ilgilidir. İkinci ise yurtiçi fiyat endeksleri üzerindeki etkidir. Yani kurlardaki değişikliklerin, ithal mallarının fiyatlarındaki değişiklikler aracılığıyla, üretici ve tüketici fiyat endeksleri üzerindeki etkisini gösterir (Dwyer ve Lam, 2004:2-7). Döviz kurlarındaki artışlar doğrudan ve dolaylı şekilde fiyat endekslerinin yükselmesine yol açmaktadır. Doğrudan etki, kurlardaki yükselmeye bağlı olarak ithal edilen hammadde, ara madde ve nihai malların ulusal para birimi cinsinden fiyatlarının yükselmesine, üretim maliyetlerinin artmasına ve maliyetlerdeki artışların da tüketici fiyatlarına yansıması yoluyla ortaya çlkmaktadır (Hyder ve Shah, 2004: 3). Dolaylı etki ise ithalata rakip mallar ile ihraç mallarının fiyatları ve emek piyasası aracılığıyla oluşmaktadır. Kurlardaki yükselme sonucu yabancı para birimi cinsinden ihraç mallarının ucuzlaması ülkelerin rekabet gücü üzerinde olumlu etkiye sahiptir. Nitekim kurların yükselmesiyle birlikte hem ithalata rakip malların hem de ihraç mallarının talebinde meydana gelen artışlar, söz konusu malların fiyatlarını yükseltici etkide bulunmaktadır (McFarlane, 2002: 6). Bu durum, söz konusu malların arzındaki artışa bağlı olarak işgücü talebini artırarak ücretlerin yükselmesine neden olmaktadır. Dolayısıyla ilgili malların fiyatlarındaki ve ücretlerdeki artış yurtiçi fiyatları etkilemektedir. Başka bir ifadeyle, fiyatlar ve ücretlerdeki artış tüketici fiyatlarına yansımaktadır. Dolayısıyla, Türkiye'de döviz kurları ve fiyatlar arasında geçiş etkisinin analiz edilmesi önem arz etmektedir. Literatürde geçiş etkisini farklı ülke ve ülke grupları ile birlikte farklı yöntemleri kullanarak inceleyen çok sayıda çalışma mevcuttur. Söz konusu çalışmalar incelendiğinde, ağırlıklı olarak eşbütünleşme ve nedensellik analizlerinin tercih edildiği görülmektedir. Ancak bu çalışmada kullanılan sürekli dalgacık uyumu (continous wavelet coherence) modelini kullanarak Türkiye için söz konusu etkiyi analiz eden herhangi bir çalışmaya rastlanılmamıştır. Dolayısıyla çalışma, bu yönüyle literatürdeki diğer çalışmalardan ayrılmaktadır.

Yukarıdaki problematikten hareketle, bu çalışmanın amacı sürekli dalgacık uyumu (wavelet coherence) modeli ile Türkiye'de döviz kurlarının fiyatlar üzerindeki geçiş etkisinin tespit edilmesine katkıda bulunmaktır. Çalışmada Türkiye Cumhuriyet Merkez Bankası Elektronik Veri Dağıtım Sistemi'nden (TCMB-EVDS) elde edilen 2010: 01-2020: 04 dönemine ait aylık Döviz Kuru (USD Kuru), Üretici Fiyat Endeksi (ÜFE), Sanayi Üretim Endeksi, İhracat Birim Değer Endeksi ve İthalat Birim Değer Endeksi'ne ait veriler kullanılmıştır. Çalışmada Matlab-2018 paket programı kullanılarak, değişkenler arası dalgalanmaların frekans değerlerini dikkate alan sürekli dalgacık uyumu modeli uygulanmıştır.

Çalışma esas itibariyle üç bölümden oluşmaktadır. Giriş bölümünden sonra konu kapsamındaki literatür özeti ikinci bölümü oluştururken, üçüncü bölüm yöntem ve analiz bulgularına ayrılmıştır. Sonuç bölümünde ise değerlendirme ve önerilere yer verilmiştir.

\section{LITTERATÜR İNCELEMESI}

Döviz kurlarının fiyatlar üzerindeki etkisi ile ilgili literatür incelemesi, iki temel amaç doğrultusunda yapılmıştır. Birincisi; çalışmanın kapsamı doğrultusunda, gelişmekte olan ülkelerde ve özellikle Türkiye'de döviz kurlarının fiyatlar üzerindeki etkisinin belirlenmesi için yapılan analizlerden elde edilen sonuçların derlenmesidir. İkincisi ise, söz konusu etkileri belirleyebilmek için tercih edilen analiz yöntemlerini tespit etmektir. Buradan hareketle, konu kapsamindaki Türkiye'ye yönelik çalışmalar ve bu alanda kullanılan analiz yöntemleri dikkate alınarak yaplan literatür incelemesi aşağıda yer almaktadır. 
Türkiye ile ilgili yapılan çalışmalarda ağırlıklı olarak eşbütünleşme ve nedensellik yöntemleri tercih edilmiştir. Eşbütünleșme analizlerinde genellikle Vektör Otoregresif Modeller (VAR); nedensellik analizlerinde ise Granger Nedensellik testleri kullanılmıștır. Eşbütünleşme analizlerinden VAR modelini kullanan çalışmalarda (Peker ve Görmüş, 2008; Yüncüler, 2011; Azgün, 2013; Ergin, 2015; Korkmaz ve Bayır, 2015; Alptekin vd., 2016; Türk, 2016; Şılklar vd., 2017; Kaya 2018) döviz kuru ve fiyatlar arasında anlamlı ve pozitif ilişkinin mevcut olduğu tespit edilmiştir. Diğer eşbütünleşme analizlerini tercih eden çalışmalarda da (Türkcan, 2005; Tümtürk, 2017; Akdemir ve Özçelik, 2018) benzer sonuçlara ulaşılmıştır. Nedensellik analizlerinde, genellikle döviz kurlarından fiyatlara doğru tek yönlü nedensellik ilişkisi bulunmuştur. Örneğin; Korkmaz ve Bayır (2015), Gül ve Ekinci (2016) ve Kaya (2018) döviz kurlarından ÜFE'ye doğru tek yönlü nedensellik ilişkisi olduğunu tespit etmişlerdir. Ancak Ayvaz vd. (2013)'de olduğu gibi, bazı çalışmalarda ise kur ve fiyatlar arasında çift yönlü nedensellik ilişkisi olduğu sonucuna ulaşılmıştır.

Literatürde farklı ülke ve ülke grupları için yapılan çalıșmalar incelendiğinde; yöntem olarak, Türkiye ile ilgili yapılan çalışmalarda olduğu gibi, genellikle eşbütünleşme analizlerinin kullanıldığı görülmektedir. $\mathrm{Bu}$ çalışmalarda ele alınan ülke ve ülke gruplarında ilgili dönemde kurların fiyatlar üzerindeki pozitif etkisinin varlığ $\breve{l}_{1}$ tespit edilmiştir. Bununla birlikte, söz konusu etkinin düzeyinin farklılık gösterdiği gözlemlenmiștir. Örneğin; McFarlane (2002) ve McCarthy (2007) kurların fiyatlar üzerindeki etkisinin yüksek olduğu sonucuna ulaşırken; Rowland (2004), Jiang ve Kim (2013), ve Kurtovic (2018) ise bu etkinin kısmi olduğunu tespit etmişlerdir. Ancak eșbütünleşme analizleri dıșında Dinamik GMM (Choudhri ve Hakura, 2006; Shu vd., 2008) gibi farklı yöntemler de uygulanmıştır. Ayrıca, bu alanda yapılan sınırlı sayıdaki çalışmalarda (Tiwari vd., 2013; Andrieş vd., 2014; Tiwari vd., 2015; Huang vd., 2017; Khan vd., 2018 ve Gök,
2020) sürekli dalgacık uyumu modelinin de tercih edildiği görülmüştür. Kullanılan yöntemler farklılaşsa da ulaşılan sonuçların benzer olduğu görülmektedir.

Özetle; literatürdeki çalışmalarda yöntem olarak çoğunlukla eşbütünleşme ve nedensellik analizleri kullanılmıştır. Benzer şekilde, Türkiye ile ilgili yapılan çalışmalarda da söz konusu yöntemler uygulanarak döviz kurunun fiyatlar üzerindeki etkisinin varlığı ortaya konulmaya çalışılmıştır. Ancak sürekli dalgacık uyumu modeli ile bu etkiyi Türkiye için belirlemeye çalışan sınırlı sayıda çalışmanın olması, bu çalışmanın hareket noktasını oluşturmuştur.

\section{UYGULAMA}

\subsection{Analiz Yöntemi (Dalgacık Uyumu Modeli/Wavelet Coherence Model)}

Hem finansal hem de ekonomik zaman serilerinde temel spektral ayrıștırma tekniklerinin başında Fourier ve dalgacık dönüşümleri gelmektedir. Spektral ayrıștırma tekniklerinden birisi olan Fourier dönüşümü, zaman alanındaki bir sinyalin içeriğinin analizine imkân veren bir dönüşüm tekniğidir. Fourier dönüşümünde, zaman alanındaki bir fonksiyon, frekans alanında bir fonksiyona dönüştürülür. Daha sonra fonksiyonun Fourier katsayıları her frekans için analiz edilir (Graps, 1995: 52). Fourier dönüşümü, bir sinyalin içerdiği frekansları gösterirken, hangi zaman diliminde hangi frekansların mevcut olduğu hakkında bilgi vermemektedir. Yani, Fourier dönüşümü belirli noktadaki zamana ait bilgiyi değil, bütün zaman dilimine ait bilgiyi vermektedir. Dolayısıyla Fourier dönüşümü, frekansı zamana göre değişmeyen sinyallerin analizinde başarılı bir yaklaşımdır (Arı vd., 2008: 1). Bahsedilen bu eksiklikten dolayı çalışmada ölçek tabanlı analiz yöntemi olan "dalgacık analiz yöntemi" kullanılmıștır.

Dalgacık dönüşümü (wavelet transform), Fourier dönüşümü ile karşılaştırıldığında daha yeni ve daha karmaşık bir yöntemdir. $\mathrm{Bu}$ dönüşüm, Fourier dönüşümü ile benzer matematiksel temele sahip olmasının yanı sıra 
ölçekleme adı verilen yeni bir özelliğe de sahiptir. Dalgacık dönüşümü hem frekans hem de zaman alanında eşzamanlı olarak zaman serilerini analiz eder. Durağan olmayan zaman serileri için en iyi tekniklerden birisi olan dalgacık dönüşümü, frekansın, farklı frekans bantlarına ayrılması, zaman diliminde bölümlere ayrılması ve böylece kendi frekans içeriklerinin analiz edilmesine imkân tanıyan bir yöntemdir (Zhao vd., 2004:1). Dalgacık analizi frekansların hem zaman hem de frekans bantlarında eş anlı olarak analiz edilmesine imkân tanır. Başka bir ifadeyle, dalgacık analizi yöntemi ile hem ağacı hem de ormanı aynı anda görmek mümkündür (Graps, 1995:50). Dalgacık fonksiyonu (veya anne dalgacık fonksiyonu), ölçeklendirme fonksiyonunun doğrusal bir kombinasyonu olarak da ifade edilebilmektedir. Bununla birlikte, $b \in \mathbb{R}$ and $a \in \mathbb{R}^{+}$, olmak şartıyla, her ölçeklenmiş ve dönüştürülmüş dalgacık fonksiyonu $\beta_{(a, b)}(t)$ anne dalgacığa göre aşağıdaki gibi yazılabilmektedir:

$\beta_{(a, b)}(t)=\frac{1}{\sqrt{|a|}} \beta\left(\frac{t-b}{a}\right)$

Burada $1 / \sqrt{|a|}$ terimi dalgacı̆̆ı birim varyansını belirleyen normalleşmeyi temsil eden faktördür. Anne dalgacı̆̆ı temsil eden $\beta($. $)$ ise iki kontrol parametresi olan $a$ (ölçek) ve $b$ (konum)'yi de içermektedir. Parametre $\omega$, dönüşüm ya da konum parametresidir. $\mathrm{Bu}$ değişken, zaman alanında dalgacığın konumunu ve pozisyonunu kontrol etmektedir. Eşitlikteki $a$ ise dalgacık genişliğini kontrol eden parametredir. Ayrıca dalgacığın pozisyonunu ve frekans alanındaki konumunu da gösterir. Frekans açısından değerlendirildiğinde, hızlı değișen detaylar daha düşük ölçeklerde, yani yüksek frekanslarda yakalanabilirken, daha yavaş değișen detaylar daha yüksek ölçeklerde, yani düşük frekansları yakalanabilmektedir. Bu durum frekans ve ölçek arasında negatif bir ilişki olduğunu göstermektedir. Sürekli dalgacık dönüşümü (SDD), dalgacık $\beta_{(a, b)}(t)$ ile ilgili olarak, $\ddot{\mathrm{x}}(t) \in L^{2}(\mathbb{R})$ 'nin incelenen zaman serisine belirli bir dalgacık, $\beta($.$) , olarak$ aşağıdaki gibi yazılabilir:

$W_{\ddot{\mathrm{x}}}(a, b)=$

$\int_{-\infty}^{\infty} ¥(t) \frac{1}{\sqrt{|a|}} \beta^{*}\left(\frac{t-b}{a}\right) d t$

Burada $W_{\ddot{x}}(a, \omega)$ SDD'yi temsil etmektedir. Denklemdeki * karmaşık eşlenmeyi (complex conjugation) göstermektedir. Diğer taraftan, küçük bir dalga olarak tanımlanan dalgacıklar genellikle aynı özelliklere sahip değillerdir. $\mathrm{Bu}$ bağlamda, dalgacıklar kendi özelliklerine göre farklı gruplara ayrılırlar. Bu dalgacıkların; Haar, Daubechies, Symlets, Coiflets, Biorthogonal, Gauss, Meksika şapkası, Morlet, Meyer, Shannon gibi türleri vardır. Morlet dalgacık dönüşümü hem hayali hem de gerçek kısımlara sahiptir, böylelikle hem faz hem de genliği analiz etme imkani sağlar. Morlet dalgacık analizi, zamanfrekans analizi için birçok avantaj sunar. Bu avantajlardan en önemlisi, Morlet dalgacığının frekans alanında Gauss şeklinde olmasıdır. $\mathrm{Bu}$ özellik nedeniyle, keskin kenarların olmaması, salınım olarak yanlış yorumlanabilecek dalgalanma etkilerini en aza indirir (Cohen, 2019:82). Morlet vd. (1984) dalgacik fonksiyonu şu şekilde yazılabilmektedir:

$\lambda_{\varphi}(t)=\pi^{-1 / 4}\left(\exp ^{i \varphi t}-\exp ^{-\varphi^{2} / 2}\right) \exp ^{-t^{2} / 2}$

Burada $\varphi$ parametresi, Morlet dalgacığının $\lambda_{\varphi}(t) \quad$ merkezi frekans parametresini göstermektedir. Ayrıca $\varphi$ Gauss zarfı içindeki salınımların sayısını kontrol etmektedir. Böylece $\varphi^{\prime}$ yı artırarak daha iyi frekans lokasyonu sağlamak mümkündür (Addison, 2002). Denklemdeki $\exp ^{-\varphi^{2} / 2}$ terimi karmaşık sinüs dalgasının sıfır olmayan ortalamasını düzelten, düzeltme parametresidir. Ancak $\varphi>$ 5 olduğu zaman bu durum ihmal edilebilmektedir.

İki zaman serisinin çapraz dalgacık gücü ${ }^{1}$ (cross-wavelet power), $W_{x y}(a, b)$ zaman serileri arasında her ölçekte (frekans bandı) ve her zamanda yerel kovaryans olarak tanımlanabilmektedir. İki zaman serisinin $x(t)$

$1 x=y$ olduğunda çapraz dalgacık gücü (cross-wavelet power) elde edilir. 
ve $y(t)$ çapraz dalgacık gücü ilk olarak Hudgins vd. (1993) tarafından aşağıdaki gibi tanımlanmıștır:

$W_{x y}(a, b)=W_{x}(a, b) \overline{W_{y}(a, b)}$

Burada, $W_{x}(a, b)$ ve $W_{y}(a, b), W_{x y}(a, b)$ olarak $x(t)$ ve $y(t)$ 'nin zaman serilerinin SDD 'dir. Yani çapraz dalgacık gücüdür. Çapraz dalgacık dönüşümleri, her iki zaman serisinde ve her bir ölçekte zaman serileri arasındaki yerel kovaryansı temsil eden yüksek ortak güce sahip alanları göstermektedir (Vacha ve Barunik, 2012: 243).

Aguiar-Conraria vd.'ne (2013) göre $W_{x}(a, b)$ ve $W_{y}(a, b)$ iki zaman serisinin dalgacık uyumunu (wavelet coherency) aşağıdaki gibi tanımlamaktadır:

$R_{x y}(a, b)=\frac{\left|\mathcal{S}\left(W_{x y}(a, b)\right)\right|}{\left|\mathcal{S}\left(\left|W_{x x}(a, b)\right|\right)\right|^{1 / 2}\left|\mathcal{S}\left(\left|W_{y y}(a, b)\right|\right)\right|^{1 / 2}}$

Denklemde $R_{x y}$ korelasyonu temsil etmektedir. Bu değer 0-1 arasında değişen bir parametredir. Eğer hem zaman hem de frekans alanında güçlü tutarlılık varsa korelasyon "1" e, eğer tutarlılık yok ise korelasyon "0" a eşit olacaktır. Ek olarak, $\mathcal{S}$ gerekli olan düzeltme (smoothing) parametresini ifade etmektedir. Bu düzeltme olmaz ise, tutarlılık her zaman güçlü yani " 1 " olacaktır. Faz farkı analizi, örneğin korelasyon yönü (pozitif ve negatif korelasyon) ve öncül ve geride (lead or lag) kalan ilişkisi gibi bileșenler arasındaki faz ilişkilerini tespit etmeye de imkân tanımaktadır. $x(t)$ ve $y(t)$ zaman serileri arasındaki faz farkı $\left(\xi_{x, y} \in[-\pi, \pi]\right.$ ile) ilișkisi denklem 6 'da ki gibi tanımlanabilmektedir:

$\xi_{x, y}(a, b)=\arctan \left(\frac{\jmath\left(w_{x y}(a, b)\right)}{\mathfrak{N}\left(W_{x y}(a, b)\right)}\right)$

Denklemde, $\mathcal{J}\left(W_{x y}\right)$ ve $\mathfrak{N}\left(W_{x y}\right)$ sirasiyla hayali ve gerçek bölümleri temsil etmektedirler. Eğer, $\xi_{x y} \in\left(0, \frac{\pi}{2}\right)$ ise, seri fazda hareket edecek ve $x(t) \rightarrow y(t)$ 'ye öncülük edecektir. Eğer $\xi_{x y} \in$ $\left(0,-\frac{\pi}{2}\right)$ ise, seri tekrar fazda hareket edecek ve bu durumda $y(t)$ öncü durumdadır. Eğer $\xi_{x, y} \in$ $\left(\frac{\pi}{2}, \pi\right)$ ise, değişkenler arasında anti-faz ilişsisi vardır, bu durumda seri fazın dıșına hareket edecektir ve $y(t)$ öncü durumdadır. Faz farkı $\pi$ veya $-\pi$ olduğunda bu durum anti-faz ilişkisi olduğunu göstermektedir. Ĕ̆er $\xi_{x, y} \in$ $\left(-\pi,-\frac{\pi}{2}\right)$ ise anti-faz ilişkisi vardır ve $x(t)$ öncü konumdadır. Son olarak, faz farkı sıfırda ise bu durumda, $y(t)$ ve $x(t)$ birlikte hareket edeceklerdir.

\subsection{Veri Seti ve Temel İstatistiki Özellikleri}

Çalışmanın bu bölümünde, Türkiye ekonomisine ait, değişkenlerin tanımlayıcı istatistikleri ve 2010:1-2020:4 zaman aralığında ki değişimleri ele alınmıştır. Analizde kullanılan veriler, T.C. Merkez Bankası Elektronik Veri Dağıtım Sistemi (EVDS)'nden elde edilmiştir. Grafiklerde sırasıyla; Türkiye'nin döviz kuru, üretici fiyat endeksi (ÜFE), sanayi üretimin endeksi (SÜE), ihracat birim değer endeksi (Ihracat)ve ithalat birim değer endeksine (İthalat) ait trend grafikleri ile bu değişkenlerin trend denklemlerine yer verilmiștir. Denklemlerle birlikte anlamlılık katsayı olarak ifade edilen $\mathrm{R}^{2}$ değerleri de yer almıştır. Daha sonra değişkenlere ait özet tanımlayıcı istatistikler değerlendirilmiştir.

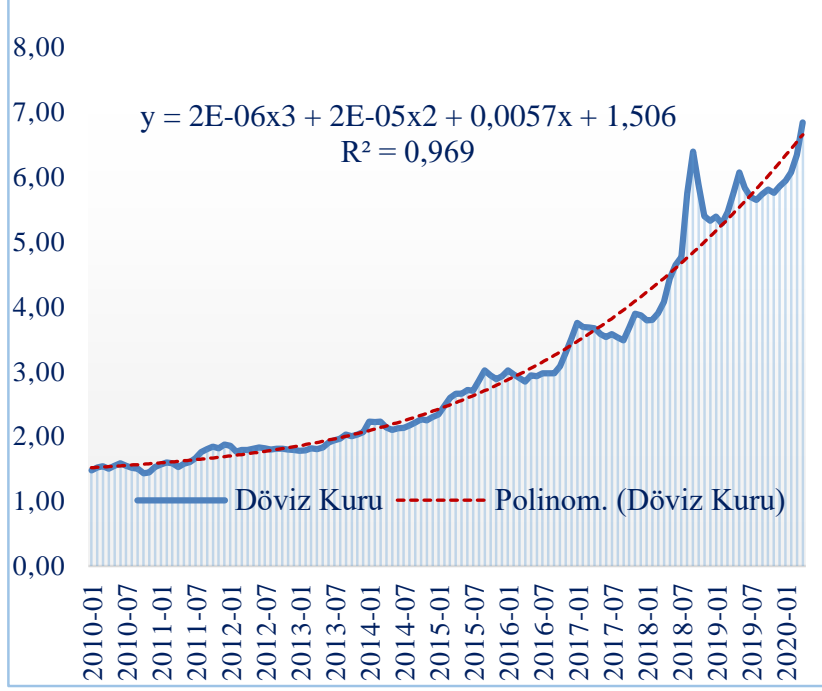

Grafik 1: Türkiye'nin Döviz Kuruna Ait Trend Grafiği

Türkiye'nin döviz kuruna ait $\mathrm{R}^{2}$ değeri 0,969 ve döviz kuruna ait polinominal denklem $\mathrm{y}=2 \mathrm{E}$ $06 \times 3+2 \mathrm{E}-05 \mathrm{x} 2+0,0057 \mathrm{x}+1,506$ 'dir. 


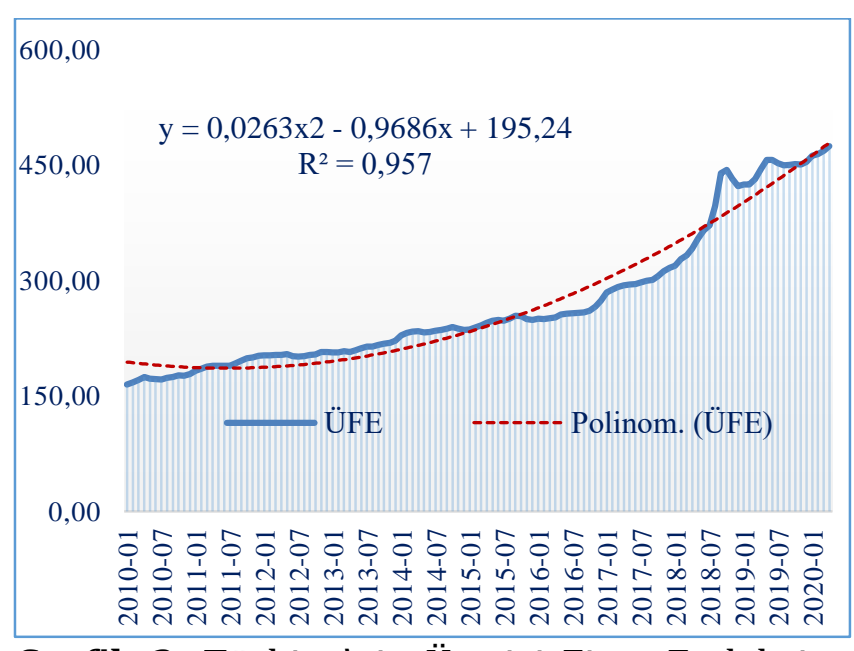

Grafik 2: Türkiye'nin Üretici Fiyat Endeksine (ÜFE) Ait Trend Grafiği

Türkiye'nin üretici fiyat endeksine ait $\mathrm{R}^{2}$ değeri 0,957 ve üretici fiyat endeksine ait polinominal denklem $y=0,0263 x 2-0,9686 x+195,24$ 'dir.

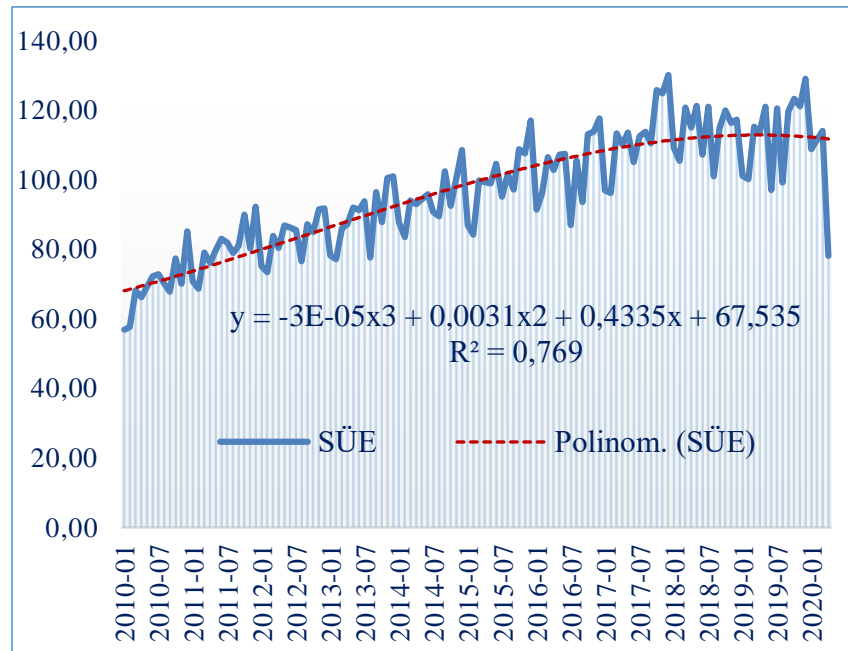

Grafik 3: Türkiye'nin Sanayi Üretim Endeksine (ÜFE) Ait Trend Grafiği

Türkiye'nin sanayi üretim endeksine ait $\mathrm{R}^{2}$ değeri 0,769 ve sanayi üretim endeksine ait polinominal denklem $y=-3 E-05 x^{3}+0,0031 x^{2}+$ $0,4335 x+67,535$ 'dir.

Türkiye'nin ithalat birim değer endeksine ait $\mathrm{R}^{2}$ değeri 0,762 ve ithalat birim değer endeksine ait polinominal denklem $\mathrm{y}=0,0001 \times 3$ 0,0279x2+1,1943x 97,225'dir.

Türkiye'nin ihracat birim değer endeksine ait $\mathrm{R}^{2}$ değeri 0,798 ve ihracat birim değer endeksine ait polinominal denklem $\mathrm{y}=9 \mathrm{E}-05 \mathrm{x} 3-0,018 \mathrm{x} 2+$ 0,8376x $+98,036$ dir.

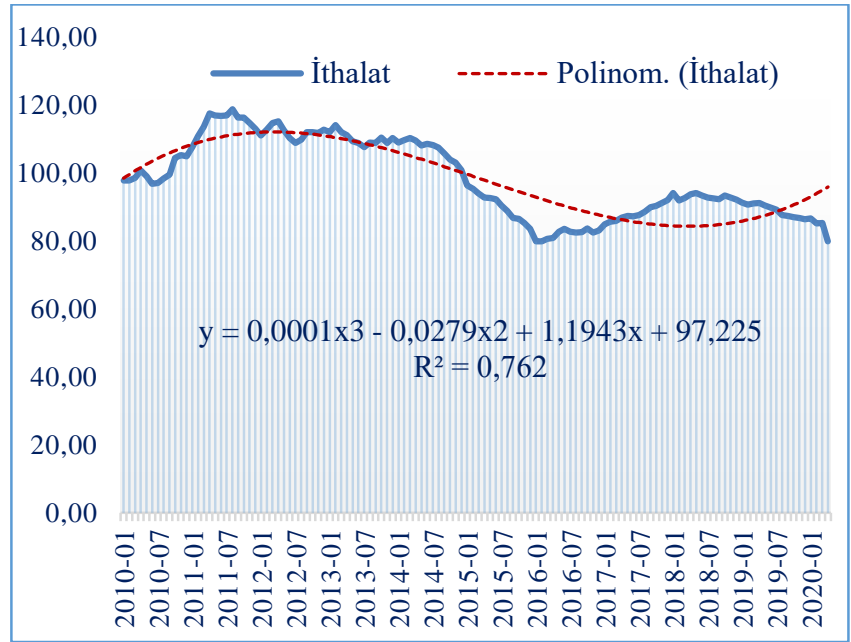

Grafik 4: Türkiye'nin İthalat Birim Değer Endeksine Ait Trend Grafiği

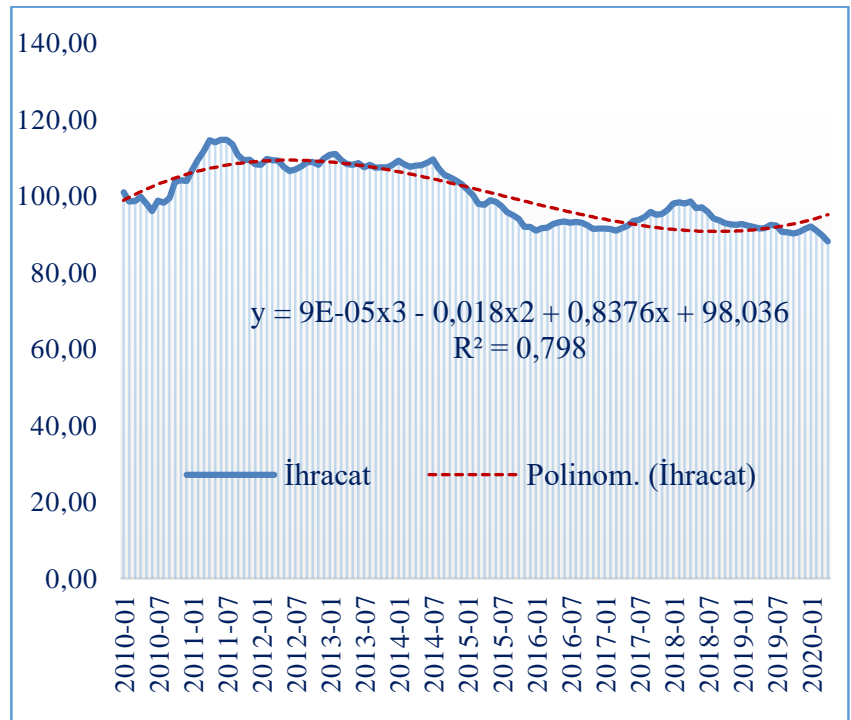

Grafik 5: Türkiye'nin İhracat Birim Değer Endeksine Ait Trend Grafiği

Grafik 1'den Grafik 5'e kadar analizde kullanılan bütün değişkenler dikkate alındığında, değişkenlerin yüksek frekansa ve yüksek $\mathrm{R}^{2}$ değerlerine sahip oldukları görülmektedir. $\mathrm{Bu}$ durum değişkenlerin dalgacık uyumu modeli analizi için uygun olduğu anlamına gelmektedir. Analizde kullanılan değişkenlere ait tanımlayıcı istatistiklere Tablo 1'de yer verilmiştir.

Tablo 1 dikkate alındığında bütün değișkenler arasında en yüksek değerlere sahip olan değişkenin üretici fiyat endeksi (ÜFE) olduğu görülmektedir. Ortanca ve ortalama değerleri açısından ÜFE'yi ihracat birim değer endeksi, ithalat birim değer endeksi ve sanayi üretim endeksi (SÜE) takip etmektedir. 
Tablo 1: Değișkenlere Ait Tanımlayıcı İstatistikler

\begin{tabular}{|l|c|c|c|c|c|}
\hline $\begin{array}{l}\text { Tanımlayıcı } \\
\text { İstatistikler }\end{array}$ & ÜFE & $\begin{array}{l}\text { Döviz } \\
\text { Kuru }\end{array}$ & SÜE & İthalat & İhracat \\
\hline Ortalama & 271.082 & 3.008 & 96.183 & 98.163 & 100.174 \\
\hline Ortanca & 240.97 & 2.524 & 95.935 & 94.66 & 98.4 \\
\hline $\begin{array}{l}\text { Standart } \\
\text { Sapma }\end{array}$ & 90.545 & 1.492 & 16.760 & 11.495 & 7.645 \\
\hline En Küçük & 164.93 & 1.425 & 56.84 & 79.8 & 88.04 \\
\hline En Büyük & 474.69 & 6.831 & 129.99 & 118.7 & 114.7 \\
\hline Gözlem Sayısı & 124 & 124 & 124 & 124 & 124 \\
\hline
\end{tabular}

\subsection{Analiz Bulguları}

Türkiye'de 2010:01-2020:4 döneminde döviz kurlarında meydana gelen değişimlerin yurtiçi fiyatlar üzerindeki geçiş etkisini araştırmak için dalgacık ve dalgacık uyumu yöntemlerinden birisi olan Morlet Dalgacık Uyumu Modeli tercih edilmiştir. Analiz sonuçlarına sırasıyla așağıda yer verilmiștir. Öncelikle ÜFE ve döviz kuru arasındaki dalgacık uyumu dikkate alınmış, ardından analizin güvenilirliği için kontrol değişkenlerin (sanayi üretim endeksi, ihracat birim değer endeksi ve ithalat birim değer endeksi) dahil edildiği dalgacık uyumu incelenmiştir. Bu çalışmadaki dalgacık analizi sonuçları, Matlab araç kutusu (toolbox) olan ASToolbox2018 kullanılarak elde edilmiștir (Aguiar-Conraria vd., 2013).

Dalgacık uyumu sonuçları sırasıyla, 1 2 frekans bandı ve 2 4 frekans bandında yorumlanmıştır:

Şekil 1.1.'de 2010:1-2020:4'e kadar 2 4 frekans bandında ÜFE ve döviz kuru arasındaki faz farkı yer almaktadır. Şekil 1.2.'de ise 2010:1-2020:4' e kadar 2 4 frekans bandında ÜFE ve döviz kuru arasındaki faz farkı yer almaktadır.

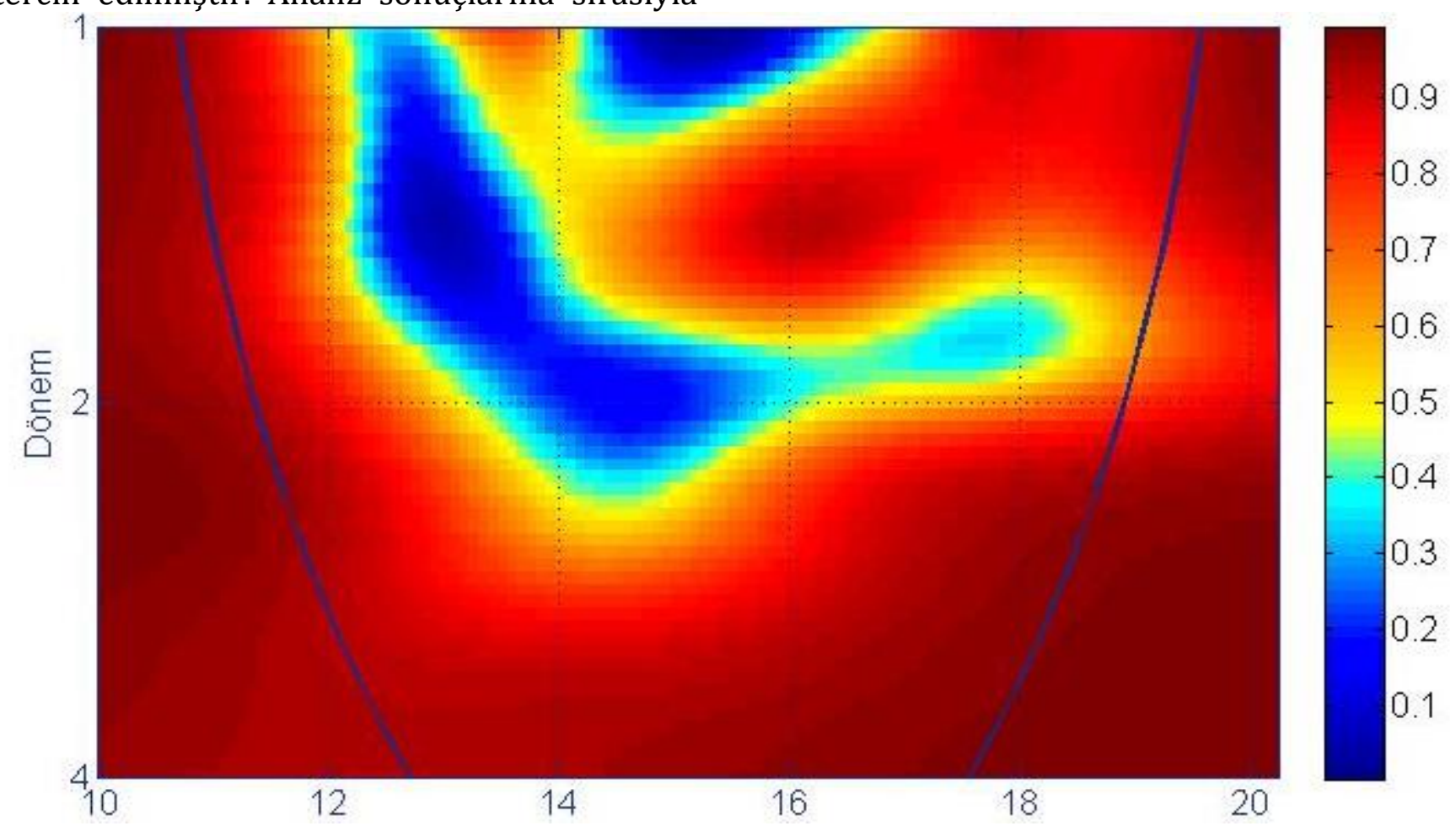

Şekil 1: Dalgacık Uyumu (Wavelet coherence) (ÜFE-Döviz Kuru)

\footnotetext{
i. Dalgacık uyumu analizinin Matlab kodunda; $\mathrm{dt}=1 / 12$; $\mathrm{dj}=1 / 30$; lower period=1; upper period=4 değerleri kullanılmıștır.

ii. Şekil 1' in x ekseni dönemleri (kısa ve uzun dönem), y ekseni yılları göstermektedir.

iii. SSekil 1'de ki mavi eğri (koni), ARMA $(1,1)$ gösterimi vasıtasıyla tahminin $\% 5$ 'lik anlam düzeyini belirtmektedir.

iv. ARMA modeli bakımından AR (1) ve MA (1) terimleri, sırasıyla bir gecikmeli otoregresif modeli ve bir gecikmeli hareketli ortalamayı temsil etmektedir.

v. S Şekil 1'in yanında ki renk kod çubuğu, değişkenler arasındaki zayıf tutarlılıktan (mavi), güçlü tutarlılığa (kırmızıya) kadar olan aralığı göstermektedir.
} 


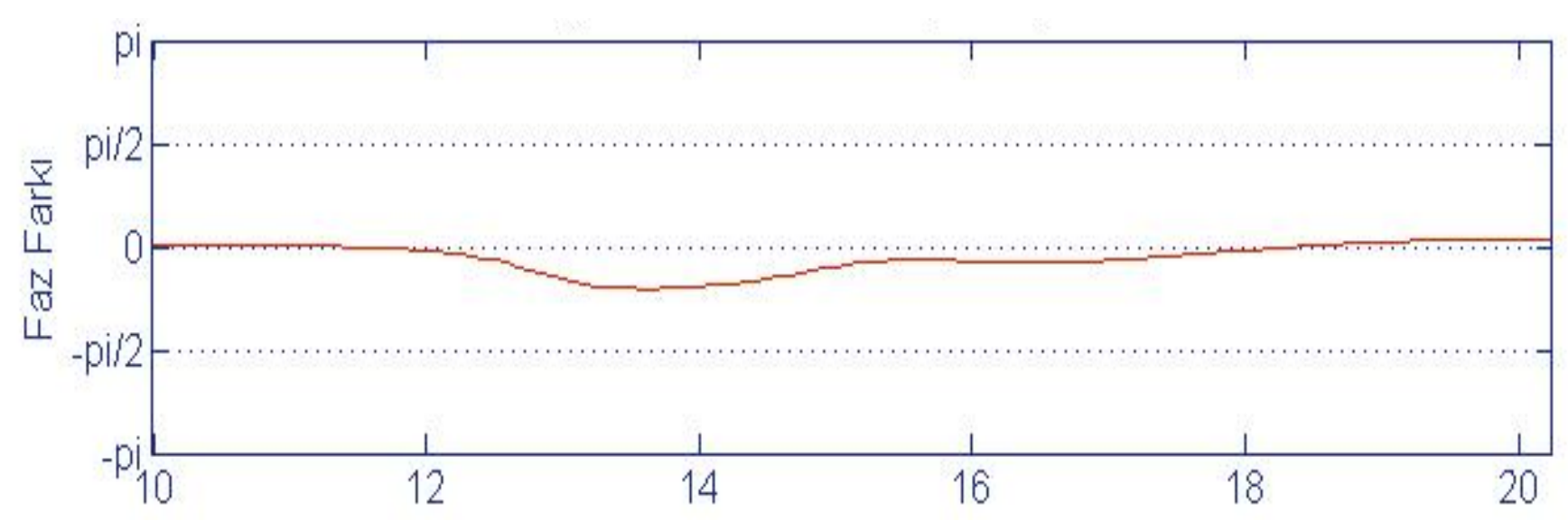

Şekil 1.1: 1 2 Frekans Bandı (2010:1-2020:4)

**1 2 frekans bandı analizinin Matlab kodunda, lowPF1=1; upPF1=2 değerleri kullanılmıștır.

Şekil 1.1.' e göre frekansın $(0,-p i / 2)$ olduğu faz aralığında seri, fazda hareket edecek ve bu durumda $y$ öncü durumda olacaktır. Frekansın (0, pi/2) olduğu faz aralığında ise, tekrar seri fazda hareket edecek ve x öncülük edecektir.

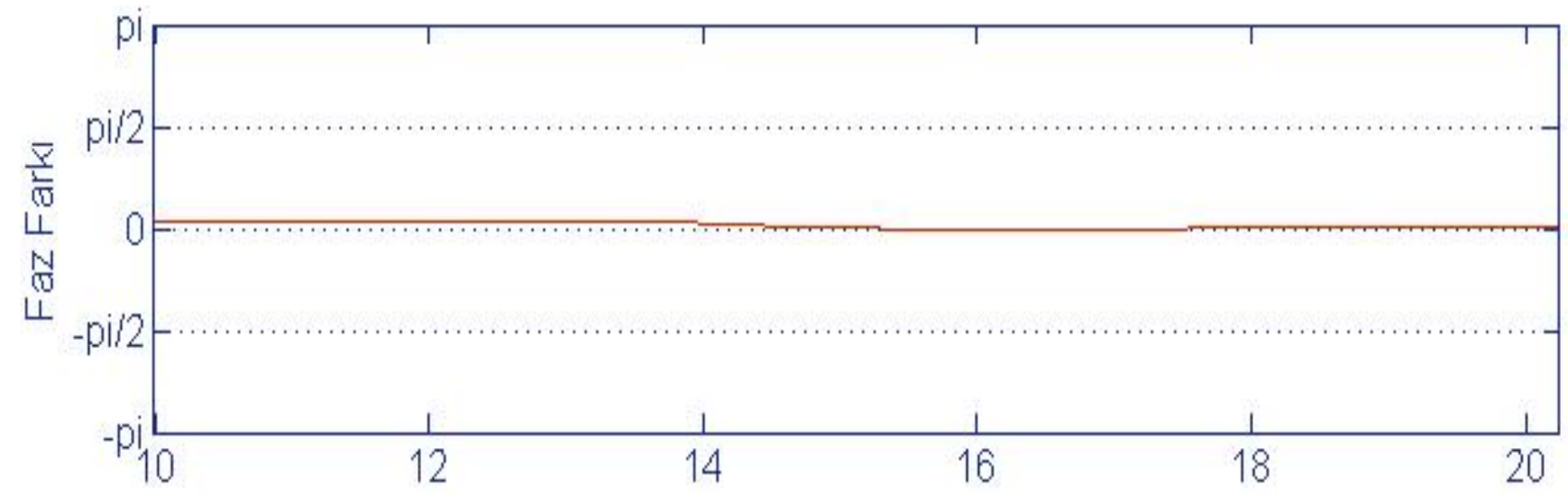

Şekil 1.2: 2 4 Frekans Bandı (2010:1-2020:4)

**2 4 frekans bandı analizinin Matlab kodunda, lowPF2=2; upPF2=4 değerleri kullanılmıştır.

Şekil 1.2.' ye göre frekansın $(0,-p i / 2)$ olduğu faz aralığında seri, fazda hareket edecek ve bu durumda $y$ öncü durumda olacaktır. Frekansın (0, pi/ 2) olduğu faz aralığında ise, tekrar seri fazda hareket edecek ve $x$ öncülük edecektir.

Şekil 1 dikkate alındığında, iki değiş̧ken arasındaki ilişkinin net olmadığı görülmektedir. $\mathrm{Bu}$ nedenle kontrol değişkenlerin modele dahil edildiği kısmi dalgacık analizlerinin yapılmasının uygun olacağı ortaya çıkmıştır.
Şekil 2, Şekil 1'deki modele kontrol değişkenlerin eklenmesi ile elde edilmiştir. Modele dahil edilen kontrol değișkenler sayesinde ÜFE ve döviz kuru arasındaki ilişkiyi gösteren dalgacık uyumu yeniden incelenmiştir. Söz konusu kontrol değişkenler sırasıyla; ihracat birim değer endeksi (ihracat), ithalat birim değer endeksi (ithalat) ve sanayi üretim endeksi (SÜE)'dir. Bu sayede, Şekil 2 ile daha spesifik dalgacık analizi elde edilmesi amaçlanmıştır. 


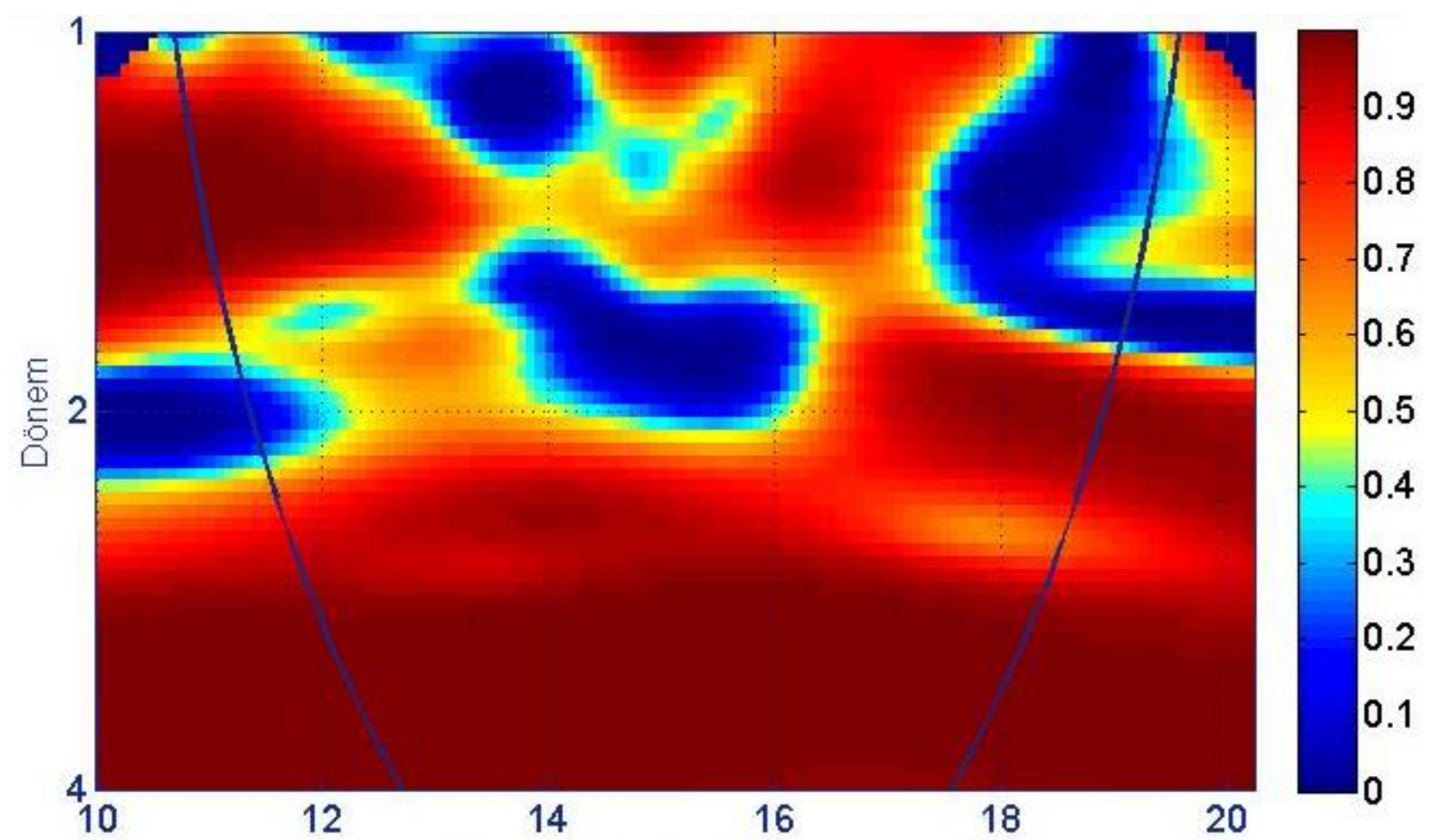

Şekil 2: Kısmi Dalgacık Uyumu/Partial Wavelet Coherence (ÜFE- Döviz Kuru, İhracat, İthalat, SÜE)

i. Kısmi dalgacık uyumu analizinin Matlab kodunda, $\mathrm{dt}=1 / 12 ; \mathrm{dj}=1 / 30$; lower period=1; upper period=4 değerleri kullanılmıștır.

ii. SŞekil 2' nin x ekseni dönemleri (kısa ve uzun dönem), y ekseni yılları göstermektedir.

iii. Ş̧ekil 2'de mavi eğri (koni), ARMA (1,1) gösterimi vasıtasıyla tahminin \%5'lik anlam düzeyini belirtmektedir.

iv. ARMA modeli bakımından AR (1) ve MA (1) terimleri, sırasıyla bir gecikmeli otoregresif modeli ve bir gecikmeli hareketli ortalamayı temsil etmektedir.

v. Şekil 2'nin yanında ki renk kod çubuğu, değişkenler arasındaki ilişkinin zayıf tutarlılıktan (mavi), güçlü tutarlılığa (kırmızıya) kadar olan aralığı göstermektedir.

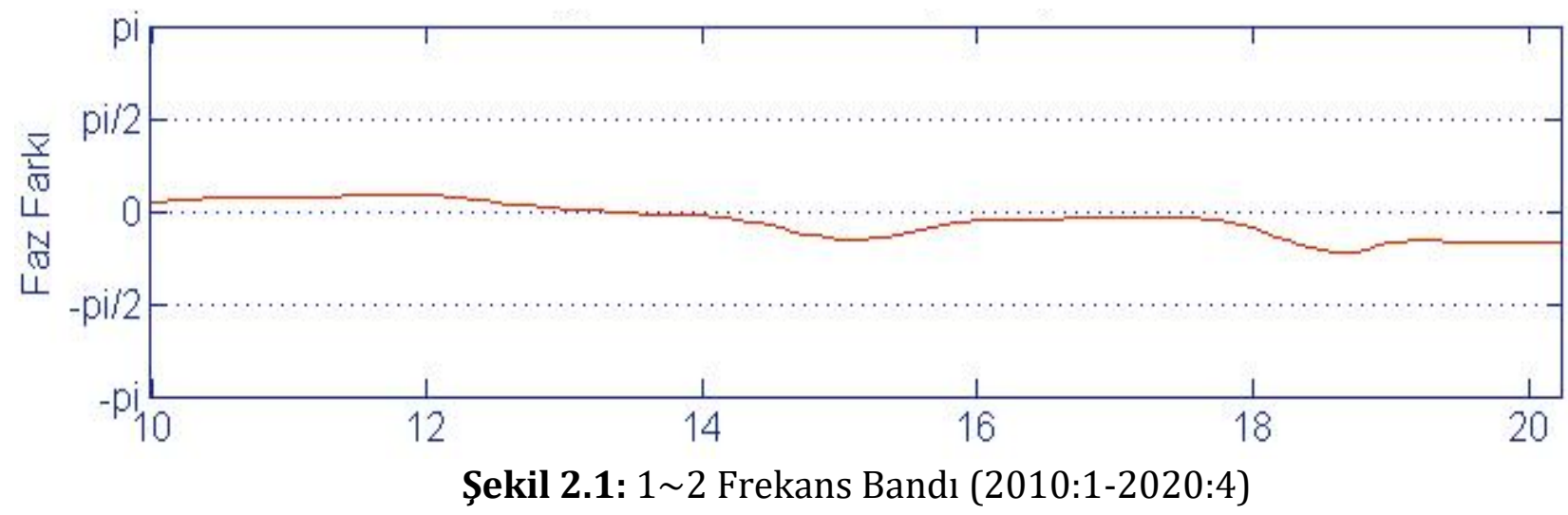

**1 2 frekans bandı analizinin Matlab kodunda, lowPF1=1; upPF1=2 değerleri kullanılmıștır.

Şekil 2.1.' e göre frekansın $(0,-p i / 2)$ olduğu faz aralığında seri, fazda hareket edecek ve bu durumda $y$ öncü durumda olacaktır. Frekansın $(0, \mathrm{pi} / 2)$ olduğu faz aralığında ise, tekrar seri fazda hareket edecek ve x öncülük edecektir. 


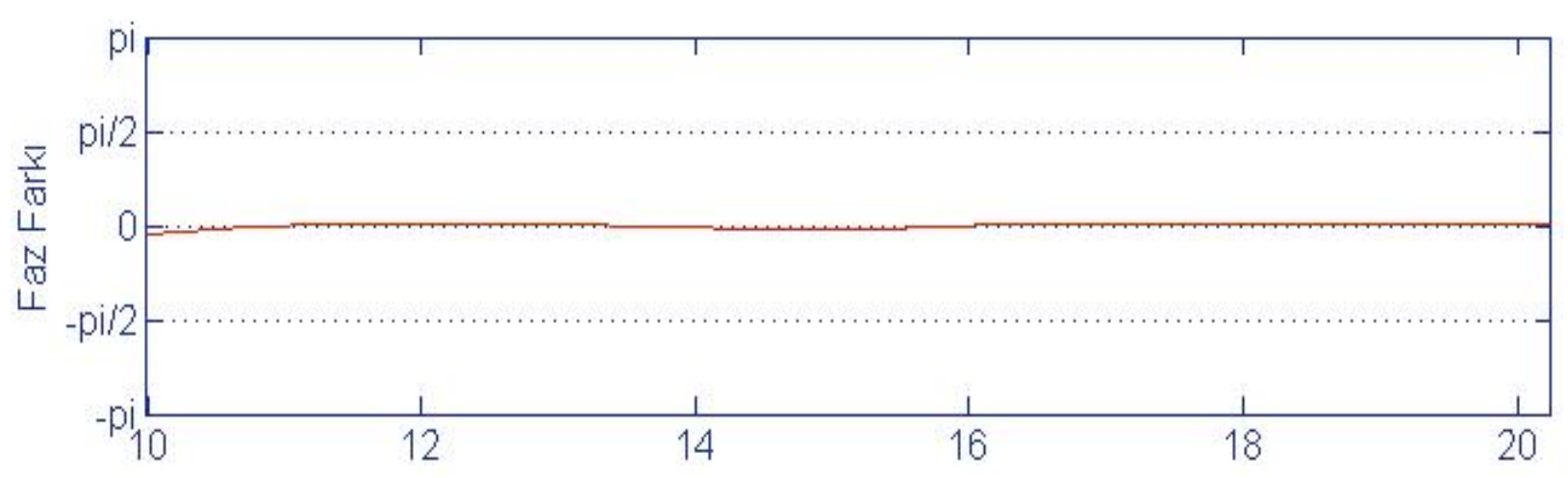

Şekil 2.2: 2 4 Frekans Bandı (2010:1-2020:4)

**2 4 frekans bandı analizinin Matlab kodunda, lowPF2=2; upPF2=4 değerleri kullanılmıştır.

Şekil 2.2.'ye göre frekansın $(0,-p i / 2)$ olduğu faz aralığında seri, fazda hareket edecek ve bu durumda $y$ öncü durumda olacaktır. Frekansın (0, pi/2) olduğu faz aralığında ise, tekrar seri fazda hareket edecek ve x öncülük edecektir.

Şekil 2, iki değişken arasında 1 2 ve 2 4 frekans aralığında korelasyonun yer aldığı bölgeleri göstermektedir. Ancak bu iki değişken arasındaki korelasyonunun yönünü anlamak için (hangi değişkenin diğerine öncül olduğunu anlayabilmek için) aşağıdaki faz farkı analizlerinin takip edilmesi gerekmektedir.

Şekil 2.1.'de 2010:1'den 2020:4'e kadar (İhracat, İthalat ve SÜE kontrol değişkenleri dalgacık modeline dâhil edildikten sonra) 1 2 frekans bandında Türkiye' de üretici fiyat endeksi ve döviz kuru arasındaki ilişkiyi gösteren faz farkı yer almaktadır. Değişkenlerin pozitif korelasyona sahip olduğu 1 2 frekans bandında 2010:1-2013:12 döneminde Türkiye' de üretici fiyat endeksindeki artış döviz kurunu artırmaktadır. Benzer şekilde 2014:1-2019:3 döneminde ise döviz kurundaki artışın üretici fiyat endeksini artırdığı görülmektedir. Şekil 2.2.'de 2010:1'den 2020:4'e kadar (İhracat, İthalat ve SÜE kontrol değişkenleri dalgacık modeline dâhil edildikten sonra) 2 4 frekans bandında Türkiye' de üretici fiyat endeksi ve döviz kuru arasındaki ilișkiyi gösteren faz farkı yer almaktadır. Türkiye' de üretici fiyat endeksi ve döviz kuru arasındaki ilişki uzun dönemli olarak incelendiği 2 4 frekans bandına göre, değişkenlerin pozitif korelasyona sahip olduğu faz bandinda, 2011:1-2013: 12 ve 2016:12018:12 dönemlerinde üretici fiyat endeksindeki artışın döviz kurunu artırdığı görülmektedir.

Son olarak çalışmada, ARMA (p, q) modeli tahmin edilerek ve Gauss dağılımından çizilen hatalarla yeni örnekler oluşturularak Monte Carlo simülasyonlarına dayalı anlamlı alanlar elde edilmiştir. Ek'de yer alan Şekil 1a ve Şekil 1b'de sirasiyla, 500 ve 1000 Monte Carlo tekrarlarıyla \%5 anlamlılık (\%95 güven aralı̆̆ı) düzeyi ile yüksek tutarlılık alanları araştırmıştır. Monte Carlo analiz bulguları analizde kullanılan kontrol değişkenlerin etkilerinin anlamlı olduğu yönünde değerlendirilmiştir.

\section{SONUÇ}

Türkiye'de 24 Ocak 1980 Kararlarından sonra diş ticarette ve 1990'lı yıllardan sonra uluslararası finansal hareketlerde meydana gelen serbestleșme, döviz kurlarının yurtiçi fiyatlar üzerindeki etkilerinin daha belirgin olmasına yol açmıştır. Bu etki; döviz kurlarında meydana gelen değişimlerin diş ticarete konu olan ihraç ve ithal mallarının fiyatları ile yurtiçi malların fiyatları ve üretim maliyetleri üzerinde etki yaratması sonucu ortaya çlkmaktadır. Türkiye gibi gelişmekte olan ülkelerin temel ekonomik hedeflerinden birisi; fiyat istikranın sağlanmasıdır. $\mathrm{Bu}$ hedefin gerçekleştirilebilmesi için söz konusu etkinin belirlenmesi önemli bir araştırma konusu 
haline gelmiştir. $\mathrm{Bu}$ bağlamda, çalışmada, Türkiye'de 2010:01-2020:04 döneminde döviz kurunun fiyatlar üzerindeki kısa ve uzun vadeli etkileri sürekli dalgacık uyumu modellerinden birisi olan Morlet Dalgacik Uyumu Modeli ile analiz edilmiștir. Analizde üretici fiyat endeksi ve döviz kuru arasındaki ilişkiyi tespit edebilmek için kontrol değişkenleri olarak sanayi üretim endeksi, ihracat birim değer endeksi ve ithalat birim değer endeksi dalgacik modeline dâhil edilmiştir. Modele dahil edilen kontrol değişkenlerinin Monte Carlo analizi neticesinde anlamlı etkilere sahip olduğu tespit edilmiștir. Elde edilen analiz sonuçları; kısa dönemde 2010:01-2013:12 periyodunda üretici fiyat endeksindeki artışların döviz kurunu artırdığını buna karşın 2014:012019:03 döneminde, kurdaki artışların üretici fiyat endeksini artırdığını göstermiştir. Uzun dönem dikkate alındığında ise, 2011:012013:12 ve 2016:01-2018:12 periyotlarında üretici fiyat endeksindeki artışların döviz kurunda artışlara yol açtığı tespit edilmiştir. Genel olarak, kısa ve uzun dönemli etkiler dikkate alındığında ise, döviz kuru ile üretici fiyat endeksi arasında pozitif ilişkinin mevcut olduğu ancak döviz kurunun üretici fiyat endeksindeki değişimlere daha duyarlı olduğu sonucuna varılmıştır.
Analizden elde edilen bulgular TCMB politikaları kapsamında değerlendirildiğinde; kısa ve uzun dönemde ortaya çlkan döviz kurunun fiyatlar üzerindeki pozitif etkilerinin söz konusu politikalara yön verdiği görülmektedir. Bu duruma, 2008 yılı Kasım ayı itibarıyla, enflasyon hedeflemesi politikasında yaşanan sapmalar, 2011 yılındaki döviz kurunun aşırı değerlenmesini önlemeye yönelik politikalar, 2015 yılında uygulanan sıkı para politikaları ve nihai olarak 2018 yılında döviz kuru oynaklığı ve sağlıksız fiyat oluşumları karşı kullanılan para politikası araçlarının genişletilmesine yönelik uygulamalar örnek olarak gösterilebilir. Sonuç olarak bu durum, Türkiye'de döviz kurlarının fiyatlar üzerinde pozitif etkisinin mevcut olduğunu göstermektedir. Dolayısıyla, literatür ile uyumlu olan sonuçlar neticesinde fiyat istikrarının sağlanması için kurlardaki artışların uygun politika araçları ile sınırlandırılması gerektiği öngörülmüştür. $\mathrm{Bu}$ etkiye yönelik uygulanacak politika araçlarının etkinliğinin incelenmesi bu alandaki araştırmacılar için yeni çalışma alanı olabilecektir.

\section{REFERANSLAR}

Addison, P. S. (2002). The Illustrated Wavelet Transform Handbook: Introductory theory and Application in Science, Engineering, Medicine and Finance, (1st Edition). Taylor \& Francis Group, CRS Press.

Aguiar-Conraria, L., Magalhães, P.C. ve Soares, M.J. (2013). The Nationalization of Electoral Cycles in the United States: A Wavelet Analysis. Public Choice, 156 (3-4), 387-408.

Akdemir, S. ve Özçelik, M. (2018). Döviz Kurlarının Yurtiçi Fiyatlara Geçiş Etkisi: Türkiye Ekonomisi 2003-2017 Dönemi Uygulaması. Ekonomik ve Sosyal Araştırmalar Dergisi, 14(1), 35-50.
Allsopp, C., Kara, A. ve Nelson, E. (2006). United Kingdom Inflation Targeting and the Exchange Rate. The Economic Journal, 116, 232-244.

Andrieş, A.M., Ihnatov, I. ve Tiwari, A. K. (2014). Analyzing time-frequency relationship between interest rate, stock price and exchange rate through continuous wavelet. Economic Modelling, 41, 227-238.

Alptekin, V., Yılmaz, K. Ç. ve Taş, T. (2016). Döviz Kurundan Fiyatlara Geçiş Etkisi: Türkiye Örneği. Selçuk Üniversitesi Sosyal Bilimler Enstitüsü Dergisi, 35, 1-9.

Arl, A. (2010). Dalgalanma Korkusu ve Döviz Kuru Geçiş Etkisi. Journal of Yasar University, 17 (5), 2832-2841. 
Arı, N., Özen, Ș. ve Özen, Ö.H. (2008). Dalgacık Teorisi (Wavelet). Ankara: Palme.

Azgün, S. (2013). Türkiye'de Döviz Kuru Hareketlerinin İç Fiyatlara (İthalat Fiyatları, ÜFE, TÜFE) Geçişi. Sosyoekonomi, 94-106.

Choudhri, E. U. ve Hakura, D. S. (2006). Exchange Rate Pass-Through to Domestic Prices: Does the Inflationary Environment Matter?. Journal of International Money and Finance, 25, 614-639.

Cohen, M.X. (2019). A better way to define and describe Morlet wavelets for time-frequency analysis. Neurolmage, 199, 81-86.

Dwyer, J. ve Lam, R. (1994). Explaining Import Price Inflation: A Recent History of Second Stage Pass-Through. Reserve Bank of Australia Research Discussion Paper, 9407, 1-43.

Ergin, A. (2015). Döviz Kuru ve Enflasyon Arasındaki Geçiş Etkisi: Türkiye Örneği. Niğde Üniversitesi İktisadi ve İdari Bilimler Fakültesi Dergisi, 8 (3), 13-29.

Graps, A. (1995). An Introduction to Wavelets. IEEE Computational Science and Engineering, 2, 50-51.

Gül, E. ve Ekinci, A. (2006). Türkiye'de Enflasyon ve Döviz Kuru Arasındaki Nedensellik İlişkisi: 1984-2003. Sosyal Bilimler Dergisi, 2006/1, 91-106.

Gök, R. (2020). Türkiye'de Borsa ve Makroekonomik Değişkenler Arasındaki Nedensellik İlişkisi: Dalgacık Bağdaşıklı̆̆ı Analizi ile Yeniden İnceleme. Erciyes Üniversitesi İktisadi ve İdari Bilimler Fakültesi Dergisi, 56, 229-254.

Huang, S., An, H., Gao, X., Wen, S. ve Hao, X. (2017). The Multiscale İmpact of Exchange Rates on the Oil-Stock Nexus: Evidence from China and Russia. Applied Energy, 194, 667678.

Hudgins L., C.A. Friehe ve Mayer, M.E. (1993). Wavelet Transform and Atmospheric Turbulence. Physical Review Letters, 71 (20), 3279-3282.
Hyder, Z. ve Shah, S. (2004). Exchange Rate Pass-Through to Domestic Prices in Pakistan. SBP Working Paper Series, No.5, State Bank of Pakistan, Pakistan.

Jiang, J. ve Kim, D. (2013). Exchange Rate PassThrough to Inflation in China. Economic Modelling, 33, 900-912.

Kaya, H. (2018). 2001 krizi Sonrası Türkiye'de Döviz Kuru ve Enflasyon İlișkisi: Döviz Kuru Geçiş Etkisinin VAR Analizi. Ankara Üniversitesi SBF Dergisi, 73(3), 841-865.

Khan, K., Su, C., Tao, R. ve Chu, C. (2018). Is There any Relationship between Producer Price Index and Consumer Price Index in the Czech Republic?. Economic ResearchEkonomska Istraživanja, 31(1), 1788-1806.

Korkmaz, S. ve Bayır, M. (2015). Döviz Kuru Dalgalanmalarının Yurtiçi Fiyatlara Etkisi. Niğde Üniversitesi İktisadi ve İdari Bilimler Fakültesi Dergisi, 8 (4), 69-85.

Kurtović, S., Siljković, B., Denić, N., Petković, D., Mladenović, S.S., Mladenović, I. ve Milovancevic, M. (2018). Exchange Rate Pass-Through and Southeast European Economies. Physica A, 503, 400-409.

McFarlane, L. (2002). Consumer Price Inflation and Exchange Rate Pass-Through in Jamaica. Bank of Jamaica, <http://boj.org.jm/uploads/pdf/papers_pamp hlets/papers_pamphlets_consumer_price_infla tion_and_exchange_rate_passthrough_in_jamaica.pdf>, 04.03.2019.

Morlet, J. ve Grossmann, A. (1984). Decomposition of Hardy Functions into Square Integrable Wavelets of Constant Shape. SIAM Journal on Mathematical Analysis, 15 (4), 723736.

Peker, O. ve Görmüş, Ş. (2008). Türkiye'de Döviz Kurunun Enflasyonist Etkileri. Süleyman Demirel Üniversitesi İktisadi ve İdari Bilimler Fakültesi Dergisi, 13(2), 187-202.

Rowland, P. (2004). Exchange Rate PassThrough to Domestic Prices: The Case of Colombia. Banco de la Republica, 
$<$ http://www.banrep.gov.co/docum/ftp/borra 254.pdf, $>, 04.03,2019$.

Shu, C., Su, X. ve Chow, N. (2008). Exchange Rate Pass-Through in Mainland China. China Economic Issues, 1(8), 1-16.

Şıklar, İ., Kocaman, M. ve Kapkara, S. (2017). Exchange pass-through to domestic prices : the Turkish case (2002-2014). Business and Economic Research, 7(2), 202-211.

TCMB (2010). Para politikası çıkış stratejisi, $<$ https://www.tcmb.gov.tr/wps/wcm/ connect/TR/TCMB+TR/Main+Menu/Yayinlar/ Para+ve+Kur/Para+ve+Kur+Politikasi+Metinl eri/>, 17.09.2019.

Tiwari, A.K., Mutascl, M.I. ve Albulescu, C. T. (2013). The İnfluence of the International Oil Prices on the real Effective Exchange Rate in Romania in a Wavelet Transform Framework. Energy Economics, 40, 714-733.

Tiwari, A. K., Bhanja, N., Dar, A.B. ve Islam, F. (2015). Time-frequency relationship between share prices and exchange rates in India: Evidence from continuous wavelets. Empirical Economics, 48 (2), 699-714.

Tümtürk, O. (2017). Türkiye'de Döviz Kurlarının Yurtiçi Fiyatlara Geçiş Etkisi ve
Enflasyon Hedeflemesi. Yönetim ve Ekonomi, 24(3), 837-855.

Türk, E. (2016). Döviz Kuru Enflasyon İlişkisi: Türkiye örneği. Ufuk Üniversitesi Sosyal Bilimler Enstitüsü Dergisi, 5 (9), 81-101.

Türkcan, K. (2005). Exchange Rate PassThrough Elasticities in Final and Intermediate Goods: the Case of Turkey. Yönetim ve Ekonomi,12 (1), 81-101.

Türkiye Cumhuriyet Merkez Bankası (TCMB), (2019), Elektronik Veri Dağıtım Sistemi, <https://evds2.tcmb.gov.tr/>, 15.05.2020.

Vacha, L. ve Barunik, J. (2012). Co-Movement of Energy Commodities Revisited: Evidence from Wavelet Coherence Analysis. Energy Economics, 34 (1), 241-247.

Yüncüler, Ç. (2011). Pass-through of External Factors into Price Indicators in Turkey. Central Park Review, 11, 71-84.

Zhao, G., Jiang, D., Diao, J. ve Qian, L. (2004). Application of Wavelet Time-Frequency Analysis on Fault Diagnosis for Steam Turbine, In:5th International Conference of Acoustical and Vibratory Surveillance Methods and Diagnostic Techniques, France, CETIM. 


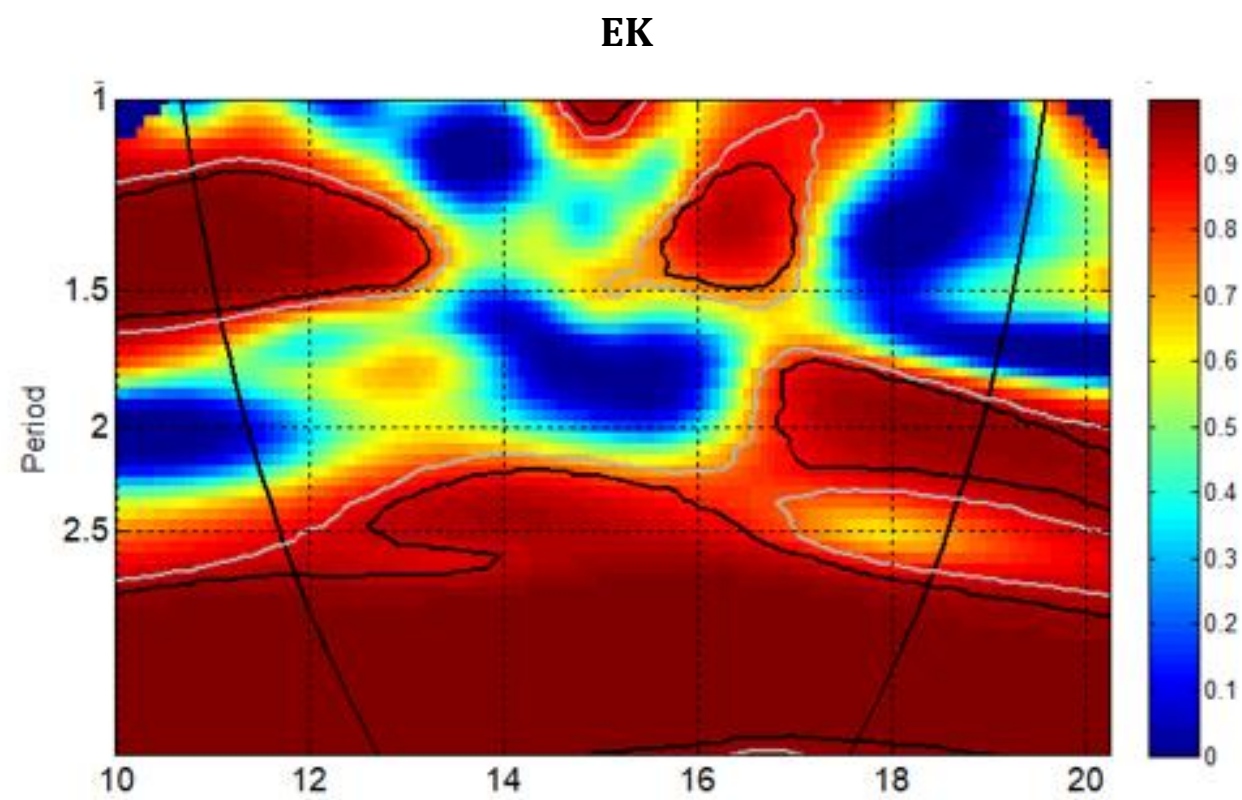

Şekil 1a. Kısmi Dalgacık Uyumu (500 replikasyonlu Monte Carlo simülasyonları ile) (ÜFE- Döviz Kuru | İhracat, İthalat, SÜE] [nsur: 500, nsur_type = 'ARMAEcon'; p = 1; q = 1]

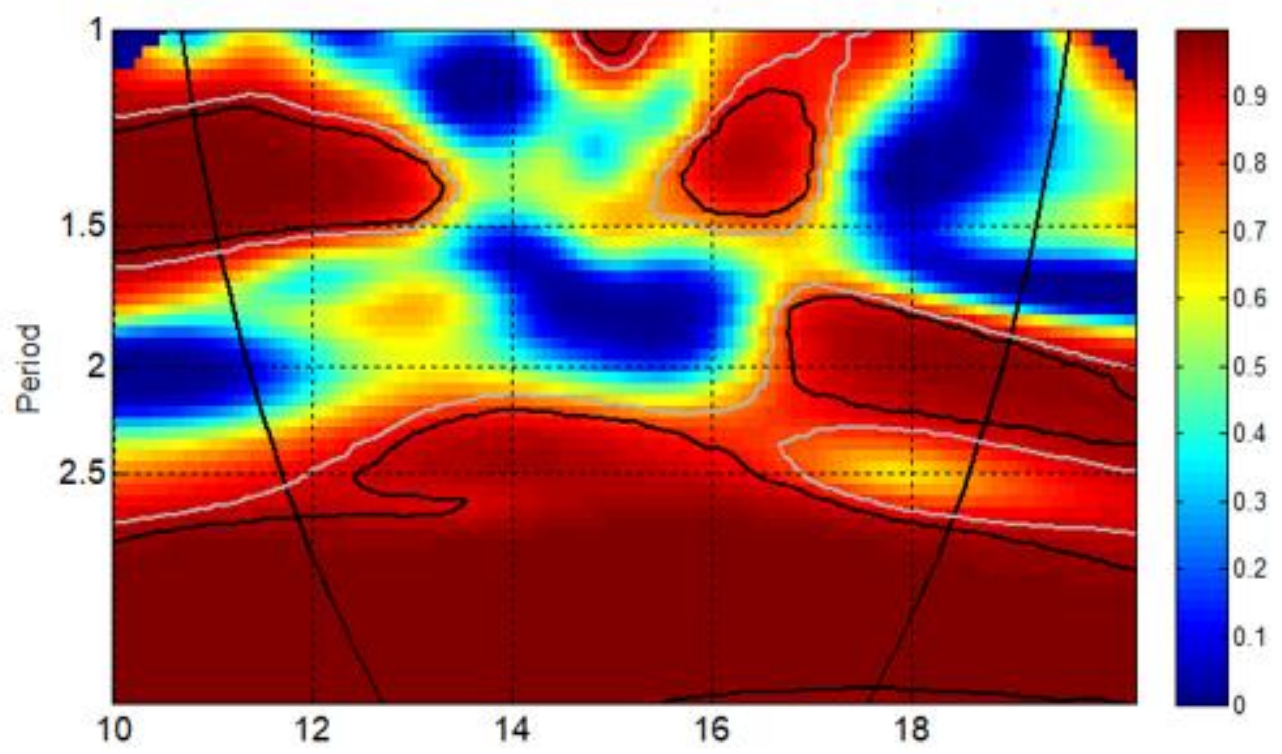

Şekil 1b. Kısmi Dalgacık Uyumu (1000 replikasyonlu Monte Carlo simülasyonları ile) (ÜFE- Döviz Kuru|| İhracat, İthalat, SÜE] [nsur: 1000, nsur_type = 'ARMAEcon'; p = 1; q = 1] 